\title{
(2) OPEN ACCESS \\ IgG4-related lung disease as a differential diagnosis of a lymphoproliferative disease: atypical presentation of an atypical disease
}

\author{
Camilo Vargas, ${ }^{1}$ Carolina Velásquez, ${ }^{1}$ Edgardo Mancilla, ${ }^{2}$ Joaquín Aracena ${ }^{1}$
}

'Department of Radiology, Universidad de Antofagasta, Antofagasta, Chile

${ }^{2}$ Department of Pathology, Hospital Regional Dr Leonardo Guzmán de Antofagasta, Antofagasta, Chile

Correspondence to Dr Camilo Vargas; bcvargas@uc.cl

Accepted 28 December 2021
D) Check for updates

(c) BMJ Publishing Group Limited 2022. Re-use permitted under CC BY-NC. No commercial re-use. See rights and permissions. Published by BMJ.

To cite: Vargas $C$, Velásquez C, Mancilla $\mathrm{E}$, et al. BMJ Case Rep 2022:15:e247295 doi:10.1136/bcr-2021 247295

\section{SUMMARY}

IgG4-related disease (IgG4-RD) is an immunomodulated inflammatory disease that usually affects the pancreas and parotid glands. Although lung involvement is rare, it has been recently reported and could mimic various other diagnoses. We present a case of IgG4-RD whose symptoms and images raised the suspicion of a malignant lymphoproliferative lung neoplasm. It is imperative to differentiate both diseases, since their treatment and prognosis vary.

\section{BACKGROUND}

This case is relevant because it shows a rare manifestation of IgG4-related disease (IgG4-RD) in the lungs, which could be mistaken for malignant neoplasms.

When vital organs are affected in IgG4-RD, effective treatment is necessary, since it can cause serious organ damage. ${ }^{1}$

\section{CASE PRESENTATION}

A 63-year-old man, with a remote history of gout and a heavy smoker, came to our clinic with a story of weight loss of $13 \mathrm{~kg}$ in 1 year, cough and dyspnoea. Physical examination demonstrated extensive inguinal and cervical enlarged lymph nodes.

\section{INVESTIGATIONS}

A CT study was performed, which showed: cervical, mediastinal, hilar, axillary, retroperitoneal and iliac lymphadenopathy (figure 1). Generalised, smooth and uniform thickening of the interlobular septa was also observed in the entire lung parenchyma

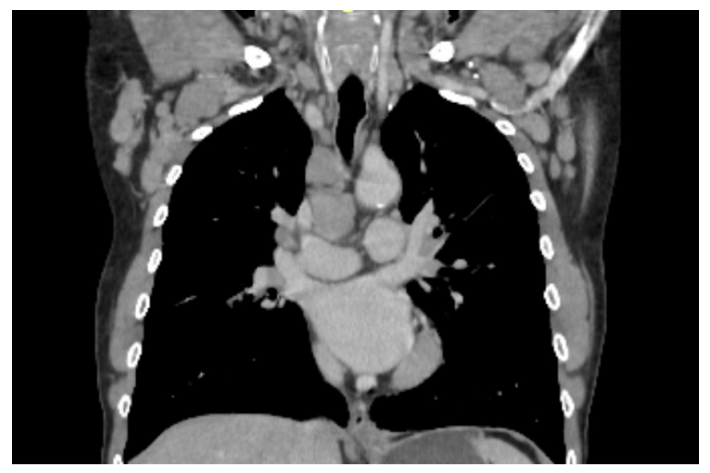

Figure 1 CT of the chest with contrast. Note the evident mediastinal, axillary, hilar and cervical enlarged lymph nodes.

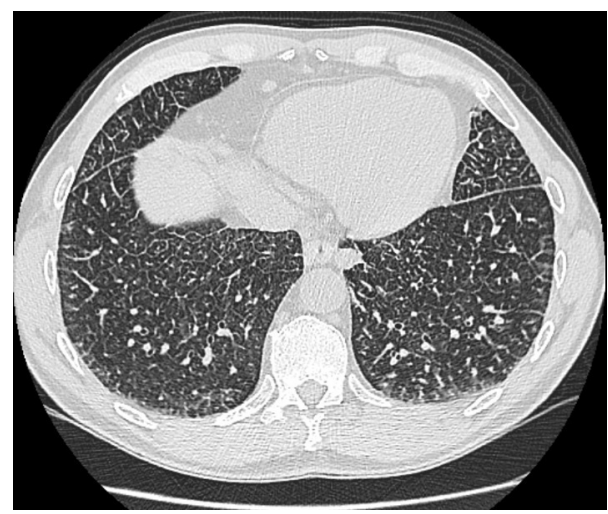

Figure 2 CT of the chest in lung window. Extensive and generalised smooth thickening of the interlobular septa.

(figure 2). There was also a spiculated mass-like image on the right apex, which had pleural retraction, air bronchogram and homogeneous density without significant enhancement (figure 3).

Blood work showed elevation of immunoglobulins in serum, particularly high IgG levels at $6161 \mathrm{mg} / \mathrm{dL}$ (normal value $<1600 \mathrm{mg} / \mathrm{dL}$ ), with IgG4 levels at 1600 (normal value $<135 \mathrm{mg} / \mathrm{dL}$ ).

Lung tissue and cervical lymph node biopsies were performed; histology was negative for malignancy and showed numerous positive IgG4 plasma cells (more than 40 positive cells per higher power field in both samples). The lung biopsy showed a mononuclear lymphoplasmacytic infiltrate with significant storiform fibrosis, and $\operatorname{IgG}$ ratio greater than $40 \%$, which was highly suggestive of IgG4-RD (figure 4).

The adenopathy also showed lymphoplasmacytic infiltration with abundant IgG4-positive plasmatic cells.

\section{DIFFERENTIAL DIAGNOSIS}

Initially, a malignant lymphoproliferative process with lymphangitic carcinomatosis of the lung was considered as the most probable diagnosis. Given the extensive adenopathies, Castleman disease was also considered, although the lack of lymph node enhancement and the lung interstitial and mass-like involvement made it less likely.

A primary lung malignancy also seemed likely; in an older, heavy smoker patient with cough and weight loss, the suspicion of primary lung cancer should be high.

Lastly, although probably lower than lymphoproliferative diseases and lung cancer, sarcoidosis 


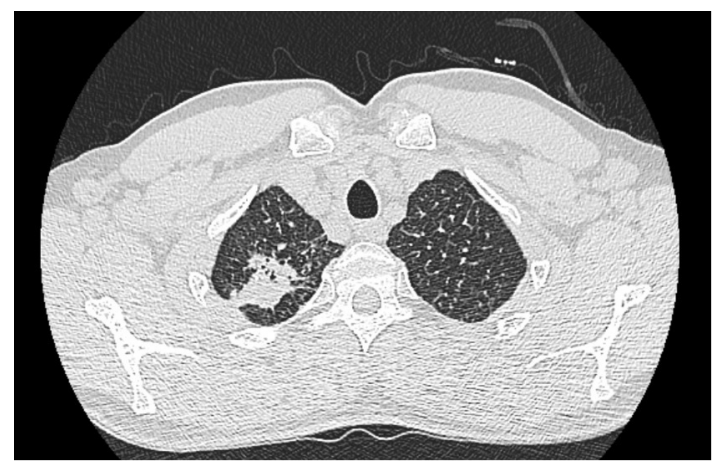

Figure $3 \mathrm{CT}$ of the chest in lung window. Irregular and spiculated mass located at the right superior lobe, highly suspicious of malignancy.

should be considered. It can typically cause lymphadenopathy (hilar, mediastinal and less typically extrapulmonary), interstitial changes and less often mass-like opacities. ${ }^{2}$

\section{TREATMENT}

Therapy with corticosteroids has been shown to be effective in both pulmonary and extrapulmonary lesions, ${ }^{3}$ although there is no consensus on the regimen for steroid maintenance therapy. The guidelines of Japanese consensus for the treatment of autoimmune pancreatitis recommend 'an initial prednisolone dosing of $0.6 \mathrm{mg} / \mathrm{kg} / \mathrm{day}$ for $2-4$ weeks, tapered every 1-2 weeks by $5 \mathrm{mg} /$ day, based on biochemical markers, clinical improvement and imaging'. ${ }^{4}$ A maintenance dose of $2.5-5 \mathrm{mg}$ is recommended, which should be discontinued after 3 years of treatment, depending on improvement after increase in dosage, considering readministration in case of relapse. ${ }^{4}$ Following that recommendation, treatment was initiated with oral prednisone $60 \mathrm{mg} /$ day, with a slow tapering plan over the two following months.

\section{OUTCOME AND FOLLOW-UP}

Prednisone therapy relieved our patient's dyspnoea and pulmonary lesions. Currently, the patient is still under corticosteroid therapy. A CT was performed 2 months after treatment, which showed remission of the right lobe mass with significantly less interstitial involvement. It is accepted that IgG4-RD must be followed up with serum levels of IgG4 in order to evaluate relapsing (up to $50 \%$ of patients show high levels of it before relapsing). ${ }^{5}$

For patients who are steroid refractory, immunosuppressants can be considered, including rituximab. ${ }^{4}$

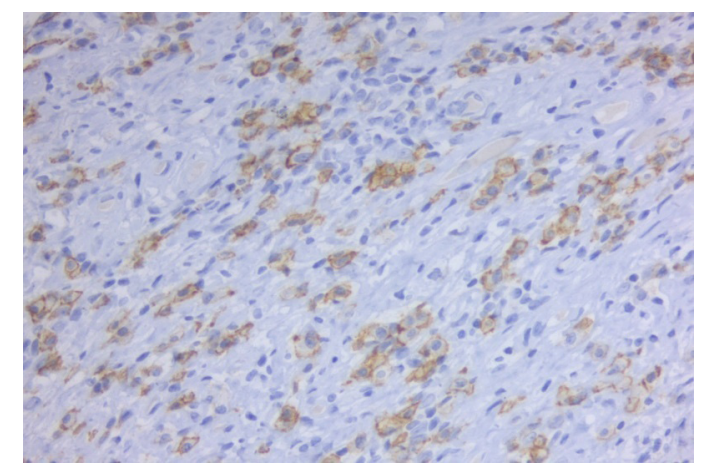

Figure 4 Lung biopsy tissue. H\&E staining, original magnification $\times 40$. The immunohistochemistry shows $\operatorname{lgG} 4 / \mathrm{lg}$-positive plasma cell ratio of $>40 \%$.

\section{DISCUSSION}

IgG4-RD is a systemic disease, consisting of tumefactive lesions with lymphoplasmacytic infiltrates with abundant IgG4-positive plasma cells, elevated IgG4 serum concentrations and storiform fibrosis. Lesions can compromise various organs, including pancreas, salivary glands, mediastinum, liver, etc. ${ }^{4}$ There have been recent reports of IgG4-related interstitial lung disease (ILD), some cases involving other organs. ${ }^{6}$

The radiological characteristics of ILD are varied and can mimic lung malignancy, usual interstitial pneumonia, organising pneumonia, non-specific interstitial pneumonia and sarcoidosis.? Inoue et al collected 13 cases of ILD and reported that it could be classified into four subtypes: a solid-nodular type, round ground-glass opacity type, alveolar interstitial type and bronchovascular type, ${ }^{8}$ being the case presented a mixture between the solid-nodular type and the bronchovascular type, given the mass-like lesion and the extensive and smooth thickening of the interlobular septa.

Elevated IgG4 serum concentration is useful for screening but does not offer a definitive diagnosis ${ }^{7}$; IgG4 serum levels $>135-$ $144 \mathrm{mg} / \mathrm{dL}$ have shown a sensitivity of $87 \%$ and a specificity of $83 \%$ according to a meta-analysis conducted by Hao et al. ${ }^{9}$

It is important to consider that in other diseases, such as bronchiectasis, asthma, emphysema, hypersensitivity pneumonitis and in approximately $5 \%$ of the general population, high levels of IgG4 in serum could be found. ${ }^{4}$

Considering this, three elements have been established as comprehensive diagnostic criteria for IgG4-RD, detailed in Umehara et al's work: (1) the presence of organ enlargement, mass or nodular lesions; (2) a serum IgG4 concentration $>135 \mathrm{mg} / \mathrm{dL}$ and (3) histopathological findings of $>10 \mathrm{IgG} 4$ cells/high power field and an $\operatorname{IgG} 4+/ \operatorname{IgG}+$ cell ratio $>40 \%$. $^{10}$

The presence of multiple adenopathies is frequent in IgG4$\mathrm{RD}$, being the first manifestation in some cases. ${ }^{11}$

When lymphadenopathy is generalised, the differential diagnosis becomes more complex. In our patient, the initial diagnosis considered lymphoma, but other diseases such as Castleman disease and disseminated malignancy were also considered as differentials. $^{12}$

Our case fulfilled the diagnostic criteria for IgG4-RD, with an extensive involvement outside the lung, therefore, the diagnosis was made.

\section{Learning points}

- Diagnosing lgG4-related lung disease (RLD) can be a challenge, since initial imaging changes tend to be nonspecific, leading to confounding interpretations, such as malignancy, infectious process or other pulmonary disorders

- The patient's clinical history, culture results (if available), pathology and laboratory results (high serum levels of lgG4) can be helpful diagnostic tools

- The spectrum of differential diagnosis of IgG4-related disease (RD) is wide, and it includes, among others, malignant primary or lymphoproliferative processes. Considering this, surgical biopsy is essential for a conclusive diagnosis

- Glucocorticoids are the first line treatment for patients with $\lg \mathrm{G} 4-\mathrm{RD}$, and a positive response supports the potential diagnosis of IgG4-RLD. However, biopsy gives the definite diagnosis. 
Contributors BV, CV, EM, JA. contributed to the design and implementation of the research, to the analysis of the results and to the writing of the manuscript.

Funding The authors have not declared a specific grant for this research from any funding agency in the public, commercial or not-for-profit sectors.

Competing interests None declared.

Patient consent for publication Consent obtained directly from patient(s).

Provenance and peer review Not commissioned; externally peer reviewed.

Open access This is an open access article distributed in accordance with the Creative Commons Attribution Non Commercial (CC BY-NC 4.0) license, which permits others to distribute, remix, adapt, build upon this work non-commercially, and license their derivative works on different terms, provided the original work is properly cited and the use is non-commercial. See: http://creativecommons.org/ licenses/by-nc/4.0/.

Case reports provide a valuable learning resource for the scientific community and can indicate areas of interest for future research. They should not be used in isolation to guide treatment choices or public health policy.

\section{REFERENCES}

1 Stone JH, Zen Y, Deshpande V. IgG4-Related disease. N Eng/ J Med 2012;366:539-51.
2 Criado E, Sánchez M, Ramírez J, et al. Pulmonary sarcoidosis: typical and atypical manifestations at high-resolution CT with pathologic correlation. Radiographics 2010;30:1567-86.

3 Kono M, Nakamura Y, Oyama Y, et al. Igg4-related disease presenting with combined pulmonary fibrosis and emphysema (CPFE). Respir Med Case Rep 2018;25:257-60.

4 Campbell SN, Rubio E, Loschner AL. Clinical review of pulmonary manifestations of IgG4-related disease. Ann Am Thorac Soc 2014;11:1466-75.

5 Palazzo E, Palazzo C, Palazzo M. Igg4-related disease. Joint Bone Spine 2014;81:27-31.

6 Wibmer T, Kropf-Sanchen C, Rüdiger S, et al. Isolated IgG4-related interstitial lung disease: unusual histological and radiological features of a pathologically proven case. Multidiscip Respir Med 2013:8:22.

7 Chen C-F, Chu K-A, Tseng Y-C, et al. IgG4-related lung disease presenting as interstitial lung disease with bronchiolitis: a case report. Medicine 2017;96:e9140.

8 Inoue D, Zen Y, Abo H, et al. Immunoglobulin G4-related lung disease: CT findings with pathologic correlations. Radiology 2009;251:260-70.

9 Hao M, Liu M, Fan G, et al. Diagnostic value of serum lgG4 for lgG4-related disease: a PRISMA-compliant systematic review and meta-analysis. Medicine 2016;95:e3785.

10 Umehara H, Okazaki K, Masaki Y, et al. Comprehensive diagnostic criteria for lgG4related disease (IgG4-RD), 2011. Mod Rheumatol 2012;22:21-30.

11 Sato Y, Yoshino T. IgG4-Related lymphadenopathy. Int J Rheumatol 2012;2012:1-8.

12 Cheuk W, Chan JKC. Lymphadenopathy of IgG4-related disease: an underdiagnosed and overdiagnosed entity. Semin Diagn Pathol 2012;29:226-34.

Copyright 2021 BMJ Publishing Group. All rights reserved. For permission to reuse any of this content visit

https://www.bmj.com/company/products-services/rights-and-licensing/permissions/

BMJ Case Report Fellows may re-use this article for personal use and teaching without any further permission.

Become a Fellow of BMJ Case Reports today and you can:

- Submit as many cases as you like

- Enjoy fast sympathetic peer review and rapid publication of accepted articles

- Access all the published articles

Re-use any of the published material for personal use and teaching without further permission

Customer Service

If you have any further queries about your subscription, please contact our customer services team on +44 (0) 2071111105 or via email at support@bmj.com.

Visit casereports.bmj.com for more articles like this and to become a Fellow 